\title{
Investigation of the Aerobic and Power Anaerobic Powers of the Students in Secondary School in Turkey
}

\author{
Albay Faruk $^{1} \&$ Kahvecioglu Çiğdem ${ }^{2}$ \\ ${ }^{1}$ School of Physical Education and Sport, Gaziosmanpasa Unıversity, Turkey \\ ${ }^{2}$ Huriye Süer Anadolu Lisesi, Turkey \\ Correspondence: Albay Faruk, School of Physical Education and Sport, Gaziosmanpasa Unıversity, Turkey. \\ E-mail: faruk.albay@gop.edu.tr
}

\author{
Received: June 20, 2019 Accepted: July 10, 2019 Online Published: July 30, 2019 \\ doi:10.5539/jel.v8n4p235 URL: https://doi.org/10.5539/jel.v8n4p235
}

\begin{abstract}
The aim of this study is to investigate the aerobic and anaerobic powers of students in different grades of the schools and describe the correlation between these powers. Upon the written approval of Samsun National Education Management, this study was carried out with the voluntary participation of 120 females and 120 males aged 11-16, who were healthy and were not active in sports. The total number of the subjects participating in the study was 240. The aerobic and anaerobic power tests of the subjects were determined through Cooper and Wingate tests respectively. All statistical calculations were evaluated through the SPSS 13 package program. The relationship between the aerobic and anaerobic powers of male and female students aged 11, 12, 13, 14, 15, and 16 was examined through Spearman correlation test. The correlations between anaerobic and aerobic powers of the subjects were as follows: 0.06 for 11 -year-olds, 0.43 for 12 -year-olds, 0.21 for 13 -year-olds, 0.24 for 14 -year-olds, 0.27 for 15 -year-olds, and 0.12 for 16 -year-olds in females while 0.13 for 11 -year-olds, 0.01 for 12 -year-olds, 0.13 for 13 -year-olds, 0.43 for 14 -year-olds, 0.23 for 15 -year-olds, and 0.56 for 16 -year-olds in males. In conclusion, no meaningful correlations between the anaerobic and aerobic powers of subjects were found.
\end{abstract}

Keywords: Anaerobic power, aerobic power, student

\section{Introduction}

The increase in sporting competitions between countries has led the physical and psychological forces of athletes to develop in a multi-faceted manner (Arslan, Arslan, \& Yildıran, 2010). The introduction of science into sport with the development of technology today and the fact that sport starts to benefit from the scientific data have increased competition and it has become a process where split seconds compete instead of seconds (Arslan \& Albay, 2019).

While aerobic metabolism is the most efficient way of obtaining energy, anaerobic metabolism is a type of metabolism used in addition to aerobic metabolism in cases where there is an urgent or excessive need or if the aerobic metabolism cannot meet the energy requirements. During an increased intensity of exercise, the necessary energy is supplied to a certain extent by the aerobic metabolism. Following this point, aerobic metabolisms become insufficient and anaerobic metabolisms become involved. The organism uses these energy production paths in the most rational way. It uses energy requirements at different densities, either prioritizing one of these ways or using both at certain proportions (Açıkada, 2004).

In a maximal voluntary exercise, the usability of working muscles based on aerobic metabolism provides the highest oxygen value and is an important physiological measure of stamina performance. The maximal aerobic power has received the attention it deserves as a criterion of performance capacity and many studies were carried out on it. The maximal oxygen consumption $\left(\mathrm{Max} . \mathrm{VO}_{2}\right)$, as a definitive indicator of aerobic power, is used to assess cardiovascular stamina and measure performance in stamina sports. However, the determination of aerobic power alone is not sufficient to measure performance in all sports branches (Harmandar et al., 2007).

The performances and physical characteristics of elite sportsmen who perform in different sports branches may vary and also anthropometric and basic motor differences may be distinctive for branches in talent identification (Arslan et al., 2010).

In recent years, it has been emphasized that there are short-term and intensive, "explosive-style" energy outputs 
rather than long-term and balanced energy production in many sports and daily activities. For example, there is a need for sudden and high power generation in moments of sudden attacks and pressured zonal defense of team sports such as football and basketball, in the attacks close to the finish line in middle distance races, in individual sports such as short distance races and swimming, in scratch sports, wrestling, tennis and several other sports branches. This sudden and large amount of power output is provided by anaerobic energy paths. The importance of anaerobic metabolism in some sporting activities requires the knowledge of anaerobic capacity. There has been a considerable increase in the number of studies in which all dynamics of anaerobic energy systems and their contribution to sports branches have been investigated since the 1990s (Bulbulian, Jeong, \& Murphy, 1996).

The high achievements of elite athletes are becoming a main goal of many countries and the high technological progresses are helping for the scientific insurance of the sport preparation and presentation (Aybek, Yetim, \& Aybek, 2019).

Aerobic and anaerobic capacities are important in determining the physical conditions of athletes. Based on the information obtained from these measurements, fitness deficiencies of the athletes are revealed and training programs are recommended. The effectiveness of the training can also be monitored with these tests. It also assists in the selection of talent, in other words, in distinguishing the most successful ones between others in a determined sport. The evaluation of aerobic and anaerobic powers will help coaches and physical education teachers to help their students select the sport they wish to do by determining their capacities. For this purpose, many test systems and methods have been developed to determine the aerobic and anaerobic profiles of athletes.

In this study, which was conducted with a large group of students aged 11-16 in the secondary schools of Ministry of National Education (MoNE), demonstrating the relationship between aerobic and anaerobic power relations and having other normative information will make a significant contribution to the selection of athletes both for coaches and physical education teachers.

\section{Materials and Methods}

This study was conducted with the participation of 240 students (120 females, 120 males) aged 11, 12, 13, 14, 15, and 16 with 20 females and 20 males in each age group. A group of students who did not have any active history in sports other than taking physical education course and who did not have a history of chronic diseases were randomly assigned to the study group.

All subjects were given detailed information about the study and the volunteers were asked to participate in the study. Within 24 hours prior to the measurements, the subjects were instructed not to perform intense physical activity, avoid coercive activities on the test day, and not to eat heavy meals three hours before the test.

With a 0.1 sensitivity, the height of the subjects were measured barefoot with the Seca brand height-weight meter while the subjects were standing in an upright position and the soles were adjacent. Using the same instrument, their body weights were measured with a $0.01 \mathrm{~kg}$ sensitivity, while they were barefoot, wearing shorts and t-shirts.

\subsection{Anaerobic Power Measurement}

Measurements were made through the Wingate anaerobic power test, the Monark 824 model bicycle ergometer, and the computer connected to the ergometer in the appropriate halls of the schools between 8.30 and $12.30 \mathrm{am}$. When the Wingate anaerobic test was explained to the subjects, it was emphasized that the subjects should pedal from the beginning to the end, in a period of 30 seconds, as fast as possible without reducing their speed. It was explained to the students before the test that their having a thought of saving the energy might affect the reliability of test results.

For optimal performance in Wingate anaerobic test, the subjects were exposed to five-minute ( 30 seconds activity, 30 seconds rest) loop warm-up. In the warm-up, preloads equal to 2 or 3 full loads were made which would end at the end of 4-8 seconds (This made the subjects feel like they were in a real test environment). To ensure psychological and motor adaptation, the warm-up was performed on the bicycle ergometer. After warm-up, the subjects were allowed to rest for 3-5 minutes to relieve the fatigue that could have occurred during this process.

75 grams of loads were applied to the subjects for per kilogram of their body weight. For Monark ergometers, the load recommended by the Wingate Institute is $75 \mathrm{~g} / \mathrm{kg}$. This load was calculated by the program automatically when data was entered into the computer. The sitting levels of the subjects were adjusted before starting the test. The sitting level was set while the subjects were sitting in the pedaling position, with the pedal in the lowest position and the knee joint was in full extension. The subjects were asked to pedal in the fastest way, with their feet attached to the pedal in such a way that they could not come off the pedal with the foot straps. When the maximum speed was reached (approximately 3-4 seconds later), a previously-calculated load of $75 \mathrm{~g} / \mathrm{kg}$ was released and the test measurement was automatically recorded. During the test, especially in the last 10-15 seconds, a very strong 
verbal motivation was made. At the end of the test, they were allowed to return to normal by pedaling for 2-3 minutes against the lightened resistance. Two measurements were made and the best measurement result was evaluated. It was determined that anaerobic power was the highest power output (peak power) in the first five seconds while anaerobic capacity, in a 30-second test, was the lowest power output as the average power output (average power) in watts and watts/kg as the minimum power output. In addition, the computer automatically calculated the power drop in watts $/ \mathrm{sec}$ and watts $/ \mathrm{sec} / \mathrm{kg}$.

\subsection{Aerobic Power Measurement}

The aerobic power measurements were performed through the Cooper test at the stadium, on a 400-meter track, between 8.30 and $12.30 \mathrm{am}$. The students were divided into groups of 15 and the subjects were given breast numbers to monitor them easily. The subjects were asked to cover as much distance as possible in 12 minutes. They were first asked to run but were told they could walk when necessary. The groups were sequentially placed at the starting line and the test was conducted when the time was started on stopwatch. They were asked to stay where they were with the final whistle, so the distance they ran was recorded. After the records were taken, the subjects continued to walk slowly for 3-5 minutes. Strong verbal motivation was performed during the test.

\subsection{Statistical Analysis}

All statistical calculations were evaluated with SPSS 13 package program and the relationship between the aerobic and anaerobic forces of male and female students at the ages of 11,12,13,14, 15 and 16 were examined with the Spearman test.

\section{Findings}

Table 1. Wingate anaerobic power mean values of females

\begin{tabular}{lllllll}
\hline & $\mathbf{1 6}$ yrs & $\mathbf{1 5}$ yrs & $\mathbf{1 4}$ yrs & $\mathbf{1 3}$ yrs & $\mathbf{1 2}$ yrs & $\mathbf{1 1}$ yrs \\
\hline Peak Power & 407.32 & 411.06 & 387.14 & 393.81 & 370.79 & 318.04 \\
Minimum Power & 211.96 & 212.12 & 197.61 & 203.67 & 202.50 & 166.66 \\
Average Power & 270.64 & 296.81 & 277.51 & 279.72 & 266.98 & 222.40 \\
Power Drop & 6.30 & 5.94 & 6.03 & 5.70 & 5.07 & 4.80 \\
Peak Power $/ \mathrm{Kg}$ & 7.52 & 7.45 & 7.60 & 7.53 & 7.46 & 7.69 \\
Minimum Power/Kg & 3.87 & 3.85 & 3.92 & 3.90 & 4.08 & 4.06 \\
Average Power/Kg & 5.39 & 5.39 & 5.42 & 5.36 & 5.36 & 5.38 \\
Power Drop/Kg & 0.12 & 0.11 & 0.12 & 0.41 & 0.09 & 0.11 \\
\hline
\end{tabular}

Table 2. Wingate anaerobic power mean values of males

\begin{tabular}{lllllll}
\hline & $\mathbf{1 6}$ yrs & $\mathbf{1 5}$ yrs & $\mathbf{1 4}$ yrs & $\mathbf{1 3 ~ y r s}$ & $\mathbf{1 2}$ yrs & $\mathbf{1 1}$ yrs \\
\hline Peak Power & 614.69 & 562.66 & 507.14 & 477.48 & 381.58 & 331.26 \\
Minimum Power & 326.47 & 303.56 & 291.58 & 256.11 & 206.78 & 201.78 \\
Average Power & 447.15 & 412.75 & 380.08 & 351.12 & 267.87 & 248.23 \\
Power Drop & 9.34 & 8.21 & 7.12 & 6.87 & 5.63 & 4.09 \\
Peak Power/Kg & 9.71 & 9.70 & 9.15 & 8.93 & 8.57 & 8.18 \\
Minimum Power $/ \mathrm{Kg}$ & 4.90 & 5.19 & 5.37 & 4.93 & 4.63 & 5.04 \\
Average Power/Kg & 7.09 & 7.10 & 6.98 & 6.54 & 5.90 & 6.19 \\
Power Drop/Kg & 0.14 & 0.14 & 0.13 & 0.13 & 0.13 & 0.10 \\
\hline
\end{tabular}

The peak power, minimum power, average power, power drop and peak power $/ \mathrm{kg}$, minimum power $/ \mathrm{kg}$, average power $/ \mathrm{kg}$, power drop $/ \mathrm{kg}$ values of male and female students $(\mathrm{n}=240)$ were presented in Tables 1 and 2 .

Table 3. The correlations between Wingate anaerobic power and physical properties (r)

\begin{tabular}{lllllll}
\hline & Male & \multicolumn{5}{c}{ Female } \\
\cline { 2 - 6 } & Age & Weight & Height & Age & Weight & Height \\
\hline Peak Power & 0.99 & 0.99 & 0.98 & 0.87 & 0.98 & 0.94 \\
Peak Power/Kg & 0.98 & 0.98 & 0.98 & -0.47 & -0.83 & -0.56 \\
Average Power & 0.98 & 0.97 & 0.97 & 0.70 & 0.95 & 0.81 \\
Average Power/Kg & 0.89 & 0.89 & 0.87 & 0.52 & 0.16 & 0.35 \\
\hline
\end{tabular}


The correlations between the physical properties of the male and female students and the variables obtained from the Wingate tests were given in Table 3.

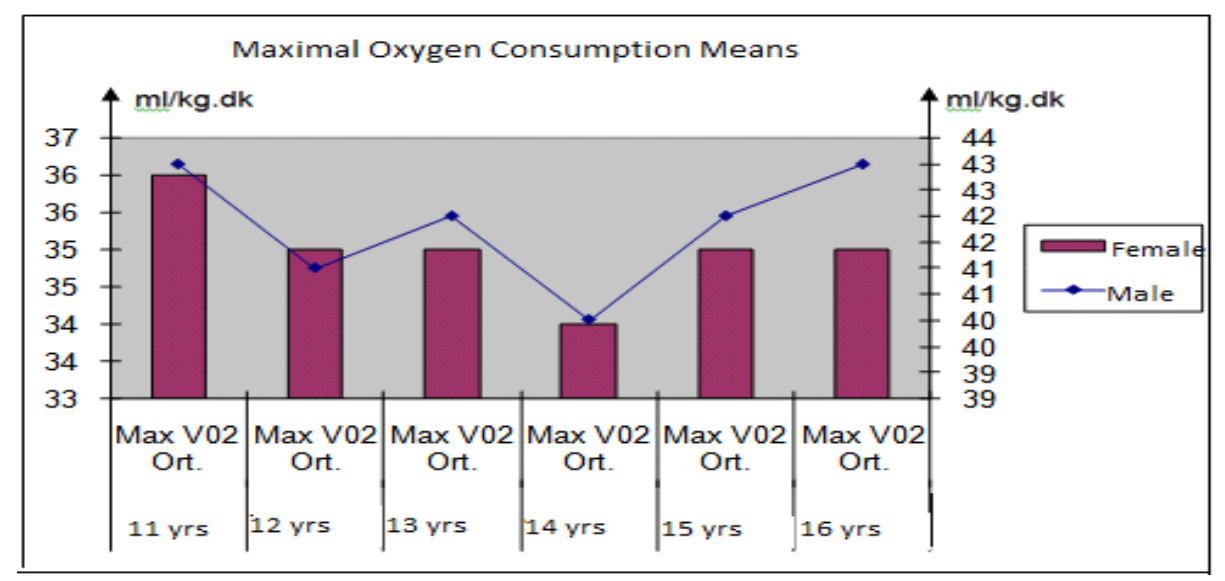

Figure 1. Max $\mathrm{VO}_{2}$ mean scores

The max $\mathrm{VO}_{2}$ mean scores of female subjects by age were $35.67 \mathrm{ml} / \mathrm{kg}$.min. for 11 year-olds, $34.87 \mathrm{ml} / \mathrm{kg}$.min. for 12 year-olds, $34.84 \mathrm{ml} / \mathrm{kg}$.min. for 13 year-olds, $33.96 \mathrm{ml} / \mathrm{kg}$. $\mathrm{min}$ for 14 year-olds, $35.11 \mathrm{ml} / \mathrm{kg}$. $\mathrm{min}$ for 15 year-olds, $34.98 \mathrm{ml} / \mathrm{kg}$.min for 16 year-olds while for male subjects, the max $\mathrm{VO}_{2}$ mean score was $43.12 \mathrm{ml} / \mathrm{kg} . \mathrm{min}$. for 11 year-olds, $41.12 \mathrm{ml} / \mathrm{kg}$.min. for 12 year-olds, $42.00 \mathrm{ml} / \mathrm{kg}$. $\mathrm{min}$. for 13 year-olds, $40.46 \mathrm{ml} / \mathrm{kg}$.min. for 14 year-olds, $42.40 \mathrm{ml} / \mathrm{kg}$.min. for 15 year-olds, and $43.23 \mathrm{ml} / \mathrm{kg}$.min. for 16 year-olds (Figure 1). The mean scores (in meters) of students in Cooper test were $1960 \mathrm{~m}$ for 11 year-olds, $1906 \mathrm{~m}$ for 12 year-olds, $1904 \mathrm{~m}$ for 13 year-olds, $1845 \mathrm{~m}$ for 14 year-olds, $1922 \mathrm{~m}$ for 15 year-olds, $1913 \mathrm{~m}$ for 16 year-olds in females while it was 2462 for 11 year-olds, $2328 \mathrm{~m}$ for 12 year-olds, $2387 \mathrm{~m}$ for 13 year-olds, $2283 \mathrm{~m}$ for 14 year-olds, $2414 \mathrm{~m}$ for 15 year-olds, and $2470 \mathrm{~m}$ for 16 year-olds in males.

Table 4. The correlations between $\mathrm{MaxVO}_{2}$ and physical properties (r)

\begin{tabular}{lllllll}
\hline & Male & \multicolumn{5}{c}{ Female } \\
\cline { 2 - 7 } & Age & Weight & Height & Age & Weight & Height \\
\hline${\mathrm{Max} \mathrm{VO}_{2}}^{0.05}$ & -0.07 & -0.08 & -0.78 & -0.63 & -0.73 \\
\hline
\end{tabular}

Table 5. The correlations between Wingate anaerobic power and $\mathrm{MaxVO}_{2}(\mathrm{r})$

\begin{tabular}{|c|c|c|c|c|c|c|c|}
\hline & & 11 yrs & $10 \mathrm{yrs}$ & $9 \mathrm{yrs}$ & $8 \mathrm{yrs}$ & $7 \mathrm{yrs}$ & $6 \mathrm{yrs}$ \\
\hline \multirow[t]{4}{*}{$\mathbf{F}$} & Peak Power- $\mathrm{MaxVO}_{2}$ & $-0,12$ & 0,27 & $-0,24$ & 0,21 & $-0,43$ & $-0,06$ \\
\hline & Peak Power/kg- $\mathrm{MaxVO}_{2}$ & 0,11 & 0,44 & 0,55 & 0,46 & 0,38 & 0,37 \\
\hline & Average Power - $\mathrm{MaxVO}_{2}$ & 0,24 & 0,28 & $-0,09$ & 0,07 & $-0,33$ & 0,24 \\
\hline & Average Power/kg $-\mathrm{MaxVO}_{2}$ & 0,64 & 0,38 & 0,53 & 0,24 & 0,59 & 0,25 \\
\hline \multirow[t]{4}{*}{$\mathbf{M}$} & Peak Power - $\mathrm{MaxVO}_{2}$ & $-0,56$ & $-0,23$ & $-0,43$ & $-0,13$ & $-0,01$ & $-0,13$ \\
\hline & Peak Power/kg- $\mathrm{MaxVO}_{2}$ & $-0,18$ & 0,22 & $-0,38$ & $-0,08$ & 0,27 & 0,43 \\
\hline & Average Power - $\mathrm{MaxVO}_{2}$ & $-0,40$ & $-0,01$ & $-0,27$ & 0,01 & 0,15 & 0,06 \\
\hline & Average Power/kg- $\mathrm{MaxVO}_{2}$ & 0,23 & 0,40 & 0,01 & 0,08 & 0,36 & 0,56 \\
\hline
\end{tabular}

\section{Discussion}

In this study, the highest aerobic power was found in 16 year-old male students. In females, except for 14-year-olds, the aerobic powers were found very close to each other. The lowest aerobic power was found in 14-year-old female and male subjects. In all age groups, the aerobic power of male subjects was higher than female subjects.

In females, depending on gender and development characteristics, the maximal $\mathrm{VO}_{2}$ values were found to be lower than males at any age. This is due to the increase in body composition in terms of gender-related increased fat mass and the fact that females have less physical activity with their social circles than males (Açıkada, 2004). 
In males and females, although maximal $\mathrm{VO}_{2}$ values show closeness in some ages, males generally have higher $\mathrm{VO}_{2}$ values in all stages before puberty. The maximal $\mathrm{VO}_{2}$ values, which show a linear increase in males up to 16 years of age, draw a plateau in girls during the adolescence after the age of 13 (Koşar \& Demirel, 2004). In parallel, the aerobic power of boys in this study showed an increase in 14-16 age groups, yet fluctuated in 11-13 age groups. No increase was observed in the aerobic power of females (Figure 1). The maximum oxygen consumption is known to be largely dependent on one's body weight and active skeletal muscle tissue. Since women are generally smaller and lighter than men in body size, body weight, and lean body mass, the maximum oxygen consumption is lower in women (Harmandar et al., 2007).

In this study as well, the maximum oxygen consumption values were found to be lower in females than males.

In a study, the aerobic power of young people between the ages of 12-16 was evaluated through the Cooper test and categorized as "perfect" up to 2950 meters, "very good" up to 2750 meters, "good" up to 2350 meters, "average" up to 1950 meters and "weak" up to 1350 meters (Akgün, 1994). When we compared the Cooper test mean scores of the subjects in our study with this literature, women were in the "average" category while men were in the "good" and "very good" categories.

In another study, the maximal $\mathrm{VO}_{2}$ mean score was found to be $40.85 \mathrm{ml} . \mathrm{kg}$.min. in males aged 14-16 (Gezgin, 1991). Also in a study conducted with males aged 13-16, the aerobic power mean was determined to be $40.95 \mathrm{ml} / \mathrm{kg}$.min. (Şenel, 1995). Although our study group was sedentary, our max. $\mathrm{VO}_{2}$ findings were compatible with those of the aforementioned studies.

In a study conducted with 144 children ( 92 males and 52 females), the aerobic power mean was found to be $27.2 \mathrm{ml} . \mathrm{kg}^{-1} . \mathrm{min}$. in males and $26.9 \mathrm{ml} . \mathrm{kg}^{-1}$.min. in females (Harmandar et al., 2007). It is seen that the values obtained in the subjects aged 12 in our study were higher than the values obtained in the mentioned study.

In another study conducted with male subjects with a mean age of 14.29 years, the Cooper test mean was found to be $2318 \mathrm{~m}$ (Demir, 1999). In the present study, the mean Cooper test was $2283 \mathrm{~m}$ for 14 -year-old subjects. The values in these two studies were very close to each other.

The max. $\mathrm{VO}_{2}$ value of 103 male subjects measured as $43.8 \mathrm{ml} / \mathrm{kg}$.min with a mean average of 12 was found to be higher than that of 12-year-old students in our study (Koşar \& Demirel, 2004).

In similar studies, the mean max $\mathrm{VO}_{2}$ of untrained male students with a mean age of 15 was $45.6 \mathrm{ml} / \mathrm{kg} . \mathrm{min}$. (Nikolic \& Ilıc, 1992), 46.2 ml/kg. min. (Akgün, 1994) in prepubescent children, $53.3 \mathrm{ml} / \mathrm{kg}$. min. in adolescent school boys, $42.6 \mathrm{ml} / \mathrm{kg}$. min. in adolescent school girls (Gezgin, 1991). The scores in these findings were lower than the values in the current study. The maximal aerobic power in children is associated with body size, sexual maturation and sex. However, in growing individuals, these three factors differ significantly in aerobic power even when controlled. This difference is related to structural, physiological and biological differences (Koşar \& Demirel, 2004).

At the end of the study, the lowest anaerobic power was obtained in 11-year-old male and female subjects. The highest anaerobic power was obtained in 16-year-old male students and 15-year-old female students. The fact that 10 -year-old female subjects had higher aerobic power, which was seen as a striking result, was thought to be caused by the fact that the children in that class did not actively do sports but were more active. When the studies on this subject are examined, it is seen that the aerobic and anaerobic powers of the sportsmen develop actively.

Muscle mass, muscle strength, strength durability, muscle-nerve and reaction time development, muscle metabolic structure and body dimensions which increase with age in children also develop with their anaerobic performances (Koşar \& Demirel, 2004).

In this study, it was seen that anaerobic power increased in both female and male subjects with age. Anaerobic performance increases depending on body weight (Fox, Bowers, \& Foss, 1999). When we look at their correlation, a significant increase in the power values obtained in this study supports this view. Anaerobic performance increases in absolute and relative values in parallel to growth and development and the highest values are reached between the ages of 20-30. The most rapid increase in anaerobic performance was in the 9-15 age group in both sexes. The women's performance in anaerobic activities was lower than that of men of the same age (Koşar \& Demirel, 2004). In this study, parallel results were obtained.

In a study conducted with boys aged 10-12, anaerobic power values (Demir, 1999) determined as $2.05 \mathrm{~W} / \mathrm{kg}$ per kilogram were lower than the anaerobic power $/ \mathrm{kg}$ values obtained from the participants aged 12 in our study.

The data obtained in a study with 18 boys aged 7-11 who were not partially active were as follows: ZG $215.5 \pm$ 41.8W, MG 182.7 $\pm 46.7 \mathrm{~W}, \mathrm{ZG}(\mathrm{W} / \mathrm{kg}) 6.3 \pm 1.2, \mathrm{MG}(\mathrm{W} / \mathrm{kg}) 5.2 \pm 1.3$ (Fox, Bowers, \& Foss, 1999). In another 
study conducted with 32 children (20 females and 12 males) aged 7-11, the values were $Z G(W) 271.9 \pm 75.6$, $\mathrm{ZG}(\mathrm{W} / \mathrm{kg}) 6.3 \pm 1.2, \mathrm{MG}(\mathrm{W}) 143.1 \pm 47.3, \mathrm{MG}(\mathrm{W} / \mathrm{kg}) 3.3 \pm 0.7$ (Boas, Joswiak, \& et al., 1996). The mean scores in another study conducted with 12 boys aged 8-12 were ZG $242.9 \pm 80.7 \mathrm{~W}, \mathrm{MG} 182.7 \pm 60.0 \mathrm{~W}, \mathrm{ZG} / \mathrm{kg}$ $5.9 \pm 1.4 \mathrm{~W} / \mathrm{kg}, \mathrm{MG} / \mathrm{kg} 4.6 \pm 1.3 \mathrm{~W} / \mathrm{kg}$ (Rivera et al., 2001). In our study, the values of 11-year-old subjects were higher than these values. This may be due to the fact that the age ranges of their subjects were low and large, although their study covered subjects in the 11-12 age group.

In a study conducted with 8-17-year-old boys; values obtained from untrained boys were as follows: age 13.0 years, ZG/kg $10.8 \pm 0.4 \mathrm{~W} / \mathrm{kg}$, MG $7.0 \pm 0.3 \mathrm{~W} / \mathrm{kg}$ (Andreacci, Haile, \& Dixon, 2007). These data are close to the results obtained in our study.

In another study conducted with boys and adolescents whose values were found to be $11.8 \pm 0.5$ years for age, $\mathrm{ZG} / \mathrm{kg} 10.8 \pm 0.7 \mathrm{~W} / \mathrm{kg}, \mathrm{OG} / \mathrm{kg} 6.1 \pm 0.7 \mathrm{~W} / \mathrm{kg} ; 16.3 \pm 0.07$ years for age, $\mathrm{ZG} / \mathrm{kg} 11.5 \pm 0.6 \mathrm{~W} / \mathrm{kg}, \mathrm{OG} / \mathrm{kg} 6.9 \mathrm{~W} / \mathrm{kg}$ (Beneke, Hütler, \& Leithauser, 2007), which showed that it was lower than the peak power $/ \mathrm{kg}$ values of 11-year-old male children and 16-year-old adolescents and similar results to mean power $/ \mathrm{kg}$ values in our study.

In a study conducted on the effect of aerobic and anaerobic training programs on some physiological parameters of male students aged 13-16 (Bulbulian, Jeong, \& Murphy, 1996), the aerobic power measured by the Cooper test in the group with an average age of 14.03 years was $40.95 \mathrm{ml} / \mathrm{kg}$. min while the anaerobic power measured by Sargent splash test was $57.83 \mathrm{~kg} / \mathrm{sec}$. These aerobic and anaerobic power values were similar to those we found.

In a study conducted with 32 children (20 females and 12 males) aged 7-11, the anaerobic power mean measured by WT was $271.9 \pm 75.6 \mathrm{~W}$, while the aerobic power mean was $\left(\max . \mathrm{VO}_{2}\right) 40.7 \pm 7.0 \mathrm{ml} / \mathrm{kg} \cdot \mathrm{min}$ (Marjerrison, Lee, \& Mahon, 2007).

In our study, the values obtained in the age group of 11 were close to the mean values of aerobic power measured above and higher than the average of anaerobic power.

As a result, it is the most important result of this study that there was no scientific relationship between the aerobic and anaerobic powers of the male and female students who do not actively participate in sports. According to this study, these powers (anaerobic and aerobic) of the subjects in these age groups who are not involved in sports do not affect one another positively or negatively. In this sense, the relationship between the two powers in sports groups, and even according to the types of sports will be more useful for sport sciences.

\section{References}

Açıkada, C. (2004). Training in children. Acta Orthopaedıca et Traumatologıca Turcıca, 38(1), 16-26.

Akgün, N. (1994). Exercise and sport physiology. Ege University Press, 1-2.

Andreacci, J. L., Haile, L., \& Dixon, C. (2007). Influence of testing sequence on a child's abilityto achieve max. anaerobic and aerobic power. Int $J$ Sports Med.

Arslan, F. N., Arslan, Y., \& Yıldıran, İ.(2010). Müsabaka Öncesi Yapılan Masajın Futbolcuların Durumluk Kaygı Düzeylerine Etkisi. Gazi Beden Eğitimi ve Spor Bilimleri Dergisi, 15(1), 11.

Arslan, Y., \& Albay, F. (2019). The relation between isokinetic strength, shoulder mobility and ball velocity at elite male volleyball players. Universal Journal of Educational Research, 7(3), 848.

Arslan, Y., Senel, O., Ibrahim, Y., Bakır, M. A., \& Akarcesme, C. (2010). Comparison of some anthropometric characteristics of elite badminton and tennis players, Ovidius University Annals, Series Physical Education and Sport/Science. Movement and Health, 5 .

Aybek, A., Yetim, A., \& Aybek, S. (2019). The Study of Psychological Endurance of Elite Athletes in Turkey Depending on Their Ages and The League Playin in. Universal Journal of Educational Research, 7(4), 937.

Beneke, R., Hütler, M., \& Leithauser, R. M. (2007). Anaerobic performance and metabolism in boys and male adolescents. Eur J Appl Physiology.

Boas, S. R., Joswiak, M. L., Nixon, P. A., Kurland, G., Oconnor, M. J., Bufalino, K., \& Orenstein, D. M. (1996). Whiteside, T. L. Effects of anaerobic exercise on the immune system in eight-to seventeen-year-old trained and untrained boys. The $J$ of Pediatrics, 129.

Bulbulian, R., Jeong, J. W., \& Murphy, M. (1996). Comparison of anaerobic components of the Wingate and Critical power tests in males and females. Med Sci SportsExerc., 28(10),1336-1341.

Demir, H. (1999). The effect of strength training on anaerobic power in 12-16 year old male badminton players. S.U. Health Sciences Institute, Turkey. 
Fox, B. F. (1999). Physiological Foundations of Physical Education and Sport. The Physiological basis of physical education and athletics. W. B. Saunders Comp. Translation Mesut Cerit, Bağırgan Press, Turkey.

Gezgin, M. (1991). Investigation of the effects of continuous loading and common interval load on the aerobic capacities of 14-16 year old boys. M.U. Health Sciences Institute, Turkey.

Harmandar, D., Gelen, E., Uçar, D., \& Saygın, Ö. (2007). Investigation of the relationship between maximal oxygen consumption capacity and body composition in children. International Journal of Human Sciences, $4(1)$.

Koşar, N. Ş., \& Demirel, H. A. (2004). Physiological characteristics of child athletes. Orthopaedıca et Traumatologica Turcıca, 38(1), 1-15.

Marjerrison, A. D., Lee, J. D., \& Mahon, A. D. (2007). Preexercise carbohydrate consumption and repeated anaerobic performance in pre-and early-pubertal boys. Int. J.of Sports Nutrition \& Exercise Metabolism.

Nikolic, Z., \& Ilıc, N. (1992). Maximal oxygen uptake in trained and untrained 15-year-old boys. British Journal of Sports Medicine, 26(1), 36-38. https://doi.org/10.1136/bjsm.26.1.36

Rivera-Brown, A. M., Alvarez, M., Rodriguez-Santana, J. R., \& Benetti, P. J. (2001). Anaerobic power and achievement of $\mathrm{vo}_{2}$ plateau in pre-pubertal boys. Int $J$ Sports Med, 22, 111-115.

Şenel, Ö. (1995). The effects of aerobic and anaerobic training programs on some physiological parameters of 13-16 year-old male students. G.U. Health Sciences Institute.

\section{Copyrights}

Copyright for this article is retained by the author, with first publication rights granted to the journal.

This is an open-access article distributed under the terms and conditions of the Creative Commons Attribution license (http://creativecommons.org/licenses/by/4.0/). 